Article

\title{
Integrating Sustainability into Construction Engineering Projects: Perspective of Sustainable Project Planning
}

\author{
Miao Yu ${ }^{1}{ }^{(0)}$, Fangwei Zhu ${ }^{1}$, Xiaotian Yang ${ }^{2, *}$, Linzhuo Wang ${ }^{1}$ and Xiuxia Sun ${ }^{1}$ \\ 1 Faculty of Management and Economics, Dalian University of Technology, No. 2 Linggong Road, \\ Ganjingzi District, Dalian 116023, China; yum@dlut.edu.cn (M.Y.); zhufwdlut@foxmail.com (F.Z.); \\ arrory@hotmail.com (L.W.); sunxiuxia@dlut.edu.cn (X.S.) \\ 2 Graduate School of Commerce, Waseda University, 1-104 Totsukamachi, Shinjuku-ku, Tokyo 169-8050, Japan \\ * Correspondence: yang12061206@fuji.waseda.jp; Tel.: +81-080-6759-6781
}

Received: 5 January 2018; Accepted: 5 March 2018; Published: 13 March 2018

\begin{abstract}
With the balanced requirement of environmental, economic and social objectives in projects intensifying, the need for integrating sustainability with project management has drawn attention in both academia and practice. Especially for large complex construction engineering projects, how to achieve sustainability-related objectives in project practices has been endowed with an irreplaceable significance. This study explores the use of project planning practices for integrating sustainability into project management practices of construction engineering projects. Sustainable project planning, as the main instrument of sustainable project management, was put forward and measured to help project managers and practitioners understand what it is and how to carry it out in construction engineering projects. Qualitative methods based on content analysis of interview data of project managers from construction engineering projects, as well as quantitative method on account of exploratory and confirmatory factor analysis of statistical data, were used to define and assess the construct of sustainable project planning (SPP). Results indicate that SPP as a project planning practice combine the principles of sustainability should consist of three dimensions-managerial control, risk response, and work consensus-to guarantee sustainable construction and predict project success of construction engineering projects. This study shed light on academics and practices concerning the sustainable management of project planning activities and the achievement of sustainable-related objectives in construction engineering projects.
\end{abstract}

Keywords: sustainable project planning; sustainability; project management; construction engineering project

\section{Introduction}

Sustainability under the context of projects have been drawing an attention due to the growing resource constraints, the increased number of stakeholders involved and the balanced requirement of environmental, economic and social objectives [1-3]. As an effort to treat environmental and social issues in the same way as economic aspects when doing business, sustainability with three components (economic, environmental and social sustainability) recently was proposed to be integrated into practices of project. Especially for the project goal and the process through which the project is managed, the requirement of sustainability will challenge the project deliverables as well as the project delivery process $[4,5]$. It requires optimizing resource allocation, planning strict schedule, and simultaneously achieving the sustainability-related objectives under such various challenging constraints, especially for large construction engineering projects [6-8]. Construction engineering projects, as typical complex and uncertain projects, over a long period of time, involve many stakeholders (i.e., governments, suppliers, designers, owners, contractors and end users), and have 
profound impacts on society $[9,10]$, are gradually required to enhance cooperation among various stakeholders, meet the series of deliverable objectives and ensure a high-level sustainability $[11,12]$. Thus, how to integrate sustainability into construction engineering project has been a challenge in the project management field.

Sustainable project management, as the practices through which projects are controlled to ensure the achievement of their goals of sustainability [13], becomes a potential area for practical implementation of sustainability. According to extant researches, sustainable project management focus on the planning, monitoring and controlling of project delivery and support processes to ensuring that project is updated and ready to face sustainability-related problems, based on the environmental, economic and social principles of the life-cycle of project's resources, processes, deliverables and effects $[5,6]$. The definition of sustainable project management involves internal and external perspective.The former related to the project management in project delivery process along project life cycle, while the later focus on the sustainable development of the project deliverable along product life cycle [14]. Because the sustainability of the project delivery process has direct impact on the results of the sustainability of project deliverable in life-cycle, it is more effective to realize sustainability in project delivery process. In this study, we focus on how to integrate sustainability into construction engineering projects from internal project management perspective.

Even though sustainable project management has been put forward to integrating sustainability into project management, it is still an overlooked and difficult area. Several researches explored the practices of integrating sustainability into project management from the perspective of critical success factors, project portfolio management, project control and so on $[1,11,15]$. Compared with other practices, project planning as a leading practice of project management process should be paid more attention with the goal of realizing sustainable project management effectively and successfully in the project life cycle. As one of the main compositions of sustainable project management, project planning was seen as a system thinking and arrangement process related to project life cycle. It takes place both outside (through local, regional and legal requirements) and inside the project organization at different levels and guides the process of the project delivery to balance the various requirements of stakeholders [11]. Because of direct impact on sustainability-related objectives of construction engineering projects, such as cost, resource, schedule, stakeholders' satisfaction [16,17], it is necessary to integrate sustainability into project planning practices to ensure the projects are delivered in a sustainable way [18]. However, even if scholars and managers in the construction engineering area acknowledge the significance of project planning [19-21], it is still unclear how much effort should be made in planning activities for effectively achieving a high level of sustainability. That means that there is no common understanding of the project planning practices combined with the principle of sustainability, which was called "sustainable project planning" in this study. For integrating sustainability principles and elements into project planning practices and maximizing the leading role of project planning, it is necessary to define and develop the concept of sustainable project planning. The lack of a common understanding and measurement on sustainable project planning means lacking of a method that is useful and applicable to involve sustainable elements to projects. Thus, the definition and empirical evaluation of sustainable project planning has a fundamental role in realizing sustainability-related objectives of construction engineering projects. In previous studies, project planning has been explored and accessed from different perspectives. It can be essentially measured by schedule, budget, and scope based on the compositions of planning [19], while most of the studies focused on its processes. One group of maturity models is evaluating the overall ability of project management processes related to planning process in spite of concentrating mainly on project quality and overall processes [22]. Although the Project Management Body of Knowledge (PMBOK) also identifies $51 \%$ of project processes related to planning, it has low redundancy and flexibility [16, 23]. Project Management Planning Quality (PMPQ) consisting of project know-how processes and organizational support processes receives a great deal of attention due to the comprehensiveness [24], while it is still difficult to deal with dynamic and sustainable project environment. There are also a few 
studies exploring the planning quality evaluation by considering the roles of planning, but they involve some dimensions or questions that have not been validated. In sum, the focused tools could provide relative well-rounded frameworks of project planning. However, there is still a lack of applicable structure analysis and evaluation criteria for sustainable project planning in construction engineering projects, which explicitly explains how sustainability could be achieved by planning effectively.

Therefore, the purpose of this study is to explore sustainable project management through project planning practices in construction engineering projects. This paper aims to fill the gap in research by proposing and assessing the concept of sustainable project planning to account for sustainability in construction project management. The research questions of this study are what the sustainable project planning is in construction engineering project context and how to evaluate it for sustainable construction. In order to answer these research questions, previous researches on the definition and evaluation of project planning and the sustainable requirements for project planning were reviewed firstly in the following section. Then, the construct, sustainable project planning (SPP), was analyzed with empirical data gained from interviews and discussions of focus groups. A reliable, valid, and widely applicable scale was developed to measure it. Results show that sustainable project planning involves three dimensions to integrating sustainability into project planning practices and predicts project success in project life cycle. This study will allow researchers and practitioners in the construction engineering industry to understand and evaluate sustainable project planning accurately. It will also contribute to recognizing the efforts invested in project planning for social, ecological, and profitable delivery of the project, enhancing sustainable project planning capabilities, and guaranteeing the achievement of socially and environmentally acceptable deliverables.

\section{Literature Review}

\subsection{Defining Sustainable Project Planning}

Project management processes start with project initiation and planning followed by execution, control, and closing processes. Project planning as the first and critical process being performed is comprehensively explained in PMBOK (5th edition), which relates to 24 processes of the overall 47 project management processes [16]. Researchers have identified project planning as a significant facilitating factor in implementing projects successfully [19-21]. Thus, the definition of project planning has constantly been proposed by different standpoints, such as its compositions, approaches, processes, and roles.

Project planning is defined as a set of detailed directions to let the project team precisely understand what activities have to be performed, when it should be done, what cost and resources need to be employed for the sake of successfully generating the project deliverables [25]. Project planning can also be seen as a decision-making process concerning systematically clearing project targets, identifying activities, establishing precedence relationships, scheming time tables, defining project completion time, constantly comparing project schedule objectives and ensuring resource to meet project requirements so that various objectives of different stakeholders can be achieved by common acceptable goals and paths of action $[16,26]$. From a sustainable project management perspective, however, the project planning needs to be defined from the functions of project planning on what kind of planning activities can achieve sustainable project management, especially for construction engineering projects. The definition of sustainable project planning should combine the project planning activities together with the principle of sustainability, which need to shift the process, activities and functions of present project planning to a sustainable way to ensure social, ecological and profitable delivery of projects.

Considering the function of project planning of existing researches, the primary goal of project planning is to decrease uncertainty [27]. Planning effort has been even viewed as a risk management tool in a high-risk environment $[26,28]$. Besides, mature planning can also provide necessary tools to make objectives increasingly specific and clear, and direct the behavior of a project to enhance the execution efficiency [29]. On the sustainable comparison with actual progress and the plan details, the 
project can be achieved by timely tracking, carried out by social, ecological, and profitable deliveries, and guided to success throughout its life cycle [30]. Thus, project planning provides a basis for directing, monitoring and control. In addition, proper project planning could inform team members of the common goals to make better sense of project objectives [31]. Laufer and Tucker [32] concluded that effective engineering planning plays four distinct roles: execution, coordination, control and forecasting. Execution concerns are directing parties to implement the project. Coordinating refers to communicating with many stakeholders based on the project plan. Control involves constantly evaluating performance and taking corrective actions when project performance diverges from plans, finally, forecasting the possible risks during implementation. Limited literature views project planning directly as an instrument to maintain internal sustainability along the project life cycle or organizing roles of project planning from a sustainable project management perspective, and leaves space for expanding roles of project planning for sustainability [33]. In fact, some existing functions such as risk prevention already provides a potential chance of life cycle thinking for project planning to integrating sustainability. While the application of sustainable project planning needs a more systematic rethinking of the functions, core characteristics and methods of the concept to guarantee the sustainability-related objectives. Thus, the definition and dimensions of sustainable project planning for construction engineering projects need to be explored further.

\subsection{Previous Measurement of Project Planning}

The evaluation and measurement of sustainable project planning is the foundation to apply it in implementing sustainable project management effectively. As the sustainable project planning focuses on project planning practices with consideration of sustainability, the assessment of sustainable project planning needs to be based on the measurement of project planning. Researchers have been using several measures with different views, names, and items to analyze the project planning. From the perspective of planning contents, project planning can be essentially evaluated by schedule, budget and scope [19]. Similarly, engineering project planning effectiveness consists of cost, time, quality and man-hour variance [34]. The project planning practices in ERP were all organized along scope planning, baseline planning and risk planning practices $[35,36]$. There are also several indexes used for computing the planning level with lack of established validity. For example, preproject-planning index is computed with a weighted set of planning written documents [17], and Project Definition Rating Index (PDRI) is also a weighted score sheet mainly used for determining the level of scope definition [37].

Most studies still prefer to evaluate project planning from the process-based view. The evaluation of the planning process is one of the first-involved in the maturity models focusing on the capability of organizational processes even if it is not treated as a significant component. For example, Software Capability Maturity Model (SW-CMM), the most famous maturity model, only includes one planning process among 18 key processes areas [22]. However, planning processes attach great importance to PMBOK identifying 47 project processes, involving $24(51 \%)$ parts [16]. Zwikael and Globerson [38] proposed Project Management Planning Quality (PMPQ), one of the comprehensive measures of the planning quality, consisting of 16 items relating to project manager's know-how processes derived from the PMBOK and the other 17 items relating to organizational support processes identified mostly from existing maturity models. Even if the tools could measure planning from a comprehensive process, they still lack of flexibility. Facing the requirements of sustainability, project planning needs to be evaluated from a sustainable perspective. Hence, what role project planning plays in facilitating project sustainability and success in a project life cycle is also the critical aspect of sustainable project planning.

According to the roles of project planning, several studies also measured it from the standpoint of functions, while most of them focused on the different background and only proposed a few dimensions or questions without being validated. For example, Grover and Goslar [39] put forward the IS planning maturity construct with five questions reflecting the importance attributed by managers to goal-setting and communication in the planning process. Engineering planning was captured 
by constructability and value engineering [40]. Strategic planning is constructed by formality of written procedures and documents, comprehensiveness of strategic alternatives, participation of diverse groups and intensity of committed resources [41]. The empirical evaluation of sustainable project planning in construction engineering projects also needs to be developed from the roles for sustainability.

In sum, these measurement scales lack pertinence and specialization in defining and evaluating sustainable project planning in construction engineering context. Thus, a reliable and valid scale of sustainable project planning involves processes and functions need be developed. It will bring standardization to the study of sustainable project planning in construction engineering projects and promote sustainable project management from the perspective of sustainable project planning.

\section{Scale Development}

The need for understanding and applying sustainable project planning require an accurate measurement of this construct. With the aim of developing a reliable and valid scale of SPP in construction engineering projects, we followed the steps described by Churchil [42], with procedural refinement as recommended by Flynn and Pearcy [43] and Stratman and Roth [44]. The scale development process is shown in Table 1. Because there is no common understanding of sustainable project planning in existing researches, it is necessary to explore and explain it from the practices of integrating sustainability into project planning. Thus, we generated the initial items from interview data of project managers who conducted sustainable project planning in their construction engineering projects using content analysis firstly. Next, we collected statistical data and analyzed them with exploratory factor analysis to purify items for final scale development. Then, we analyzed another data set with confirmatory factor analysis and generate the final scale of SPP. Finally, this SPP scale development ended with evaluation of construct validity. The reliable and valid scale of SPP provides a common understanding and basis of evaluation and application of project planning practices with principle of sustainability.

Table 1. Scale development process.

\begin{tabular}{|c|c|}
\hline Stages of Scale Development Process & Details \\
\hline Defining construct and generating items & $\begin{array}{l}\text { - } 25 \text { interviews from project managers } \\
\text { - Content analysis of interview transcripts to clarify the } \\
\text { construct and extracted codes } \\
\text { - } 66 \text { free nodes were extracted and classified }\end{array}$ \\
\hline Item generation and purification & $\begin{array}{l}\text { - } \quad 66 \text { free nodes were transformed to items } \\
\text { - } \quad \text { Items were purified by adopting frequency-based } \\
\text { approach and focus group approach } \\
\text { - } \quad 25 \text { items are retained for the next step }\end{array}$ \\
\hline $\begin{array}{l}\text { Scale purifications } \\
\text { - } \quad \text { Initial reliability assessment } \\
\text { - } \quad \text { Exploratory factor analysis } \\
\text { - } \quad \text { Dimensionality } \\
\text { - } \quad \text { Item refinement and reduction }\end{array}$ & $\begin{array}{l}\text { - National survey to project managers } \\
\text { - } 14 \text { items meet the psychometric criteria and are retained } \\
\text { - } \quad \text { Nor the next and final steps }\end{array}$ \\
\hline \begin{tabular}{ll}
\multicolumn{2}{l}{ Finalization of the scale } \\
- & Confirmatory factor analysis \\
- & Convergent validity \\
- & Discriminant validity \\
- & Construct reliability \\
- & Predictive validity
\end{tabular} & $\begin{array}{l}\text { - } 14 \text { items meet the psychometric criteria and are retained } \\
\text { for the validity tests } \\
\text { - Validation of the scale }\end{array}$ \\
\hline
\end{tabular}




\subsection{Developing the SPP Scale}

\subsubsection{Generating the Items}

Even though the existing understanding of sustainable project management provides a direction for sustainable project planning, it is still unclear that what kind of efforts should be made and what is the core characteristics of sustainable project planning. Thus, twenty-five project managers from the industry of civil engineering, construction, energy, chemical engineering were interviewed to establish an understanding of sustainable project planning. Interview was stopped until theorectical saturation was reached for the concept of sustainable project planning in construction engineering projects. Participants were selected by using the stratified convenience sample approach described by Creswell [45]. All participants have more than five years' management experience of construction engineering projects, and approximately $50 \%$ of the participants have been project manager for more than ten years. Our interviews involved large percentage of experienced project managers to make sure representation of interviewees with an in-depth understanding of their projects. Interviewees were asked, "If someone described their project planning as sustainable, what would that statement mean to you?" "How do you tell the difference between a well sustainable project planning and a lower one?" "What's the requirements of sustainable project management on project planning?" Other questions were related to the perceived advantages of being a project with sustainable project planning. We recorded all interviews by audio, and eventually transcribed and analyzed them by using QSR Nvivo10.

Using the sentence as the unit of analysis, codes were developed following the "in vivo code" approach. This procedure was followed for each question in the questionnaire, generating a total of 66 codes. Next, the codes were categorized into common themes. Recognizing that categorization can condition the analytical success of a study, care was taken to categorize codes by the subject matter of each text unit. Table 2 shows the cumulative frequency counts of all themes of sustainable project planning. Project guarantee was the most frequently mentioned dimension $(96 \%)$, which reflect the role of sustainable project plan to ensuring project implementation successfully and sustainably in project life cycle. Likewise, 22 out of all 25 respondents referred to risk reduction (88\%), which indicates that sustainable project planning should reduce the risk and uncertainty about delay, waste, and cost emerging from construction engineering project life cycle. The team perception dimension appears to be more popular than external orientation $(76 \%$ vs. $52 \%$ ), which also show that sustainable project planning will pay more attention to project stakeholder's social feelings and identity in construction engineering project life cycle.

Table 2. Cumulative frequency counts of all themes.

\begin{tabular}{cccc}
\hline & Text Units & Documents & Documents\% \\
\hline Project Guarantee & 344 & 24 & $96 \%$ \\
Risk Reduction & 166 & 22 & $88 \%$ \\
Team Perception & 118 & 19 & $76 \%$ \\
External Orientation & 54 & 13 & $52 \%$ \\
Total & 771 & 25 & $100 \%$ \\
\hline
\end{tabular}

By reviewing the existing literature and the interview data, sustainable project planning was defined as a process using project planning practices to ensure social, ecological and profitable delivery of the project, which reflects the extent that a project planning process and its deliverables meet the needs of sustainability in project life cycle. Then, sustainable project planning will also guarantee the social, environmental, and economic goal of construction engineering project deliverables throughout its life cycle [13]. For example, Interviewee A point out that "The sustainable project planning refers to the extent that a project can guide the implementation process of project sustainably, which will affect the project success directly." Project Manager B emphasizes that "The sustainable project planning 
manifests the capability and the effectiveness that a project team utilizes project plan to accomplish project tasks and achieves project goal sustainably in a project life cycle". Following the qualitative analysis, 66 nodes were coded to represent the sustainable project planning.

\subsubsection{Item Purification}

Sixty-six codes were extracted from the transcripts through in vivo coding, and transferred to the corresponding items. These items were the description of the core characteristics of the sustainable project planning and often quoting or paraphrasing from the participants themselves. In order to reduce the number of items to a more manageable level while still retaining essential data characteristics, 27 items with fewer than three text units were eliminated by means of a frequency-cased approach. Participants from previous interviews were asked again to rate the 39 items on their performance in "differentiating construction engineering projects which have sustainable project planning from those have less so" in a 5-point evaluation scale. 9 items that score below three were removed. Then the list of items were discussed with eight experts from project management field in a focus group to establish content and face validity. Four project management researchers and 4 project practitioners were invited to judge all 30 items. In the beginning, participants had 10 minutes to rate the items. Subsequently, focus group discussed each item with respect to uniqueness, suitability, and ability to pass on the intended meaning. After this step, the scale retained 25 items and refined following the experts' suggestions. Appendix A shows the final list of 25 potential items for the next step.

\subsection{Statistical Assessment of the Scale}

\subsubsection{Survey}

The purposes of this statistical assessment section are to explore and examine the dimensions of sustainable project planning and develop a measuring instrument of SPP in construction engineering projects. We have conducted an online survey of construction engineering project managers in the industries (civil engineering, energy, petrochemical, transportation and so on) to collect the statistical data. Project managers are appropriate sample data for the survey which is mainly related to project-level variables. Project managers were used as single informants commonly in organization studies [1,33]. Hambrick [46] also indicated that manager's perceptions were prone to the same phenomenon compared with others in positions elsewhere. In the same way, project managers of construction engineering projects are likely to have more knowledge about the situation of project planning process and outcome in a specific project than their superior and other project team members. Based on a five-point Likert scale, respondents were asked to rate the extent to which item of sustainable project planning expressed their project. The questionnaire also included Project success (PS) Scale for validity purposes [47].

Because of the geographic distribution of samples, and the consideration of speed, accessibility within reasonable cost, we conduct the survey through the web [48]. Four-hundred sixty individuals from the well-established project manager database of the research team became the target population. Three-hundred fifteen responses were received, indicating $68.48 \%$ of those contacted. 12 cases were eliminated due to incomplete (more than 20\%) and consistent response, leaving 303 usable cases for analysis (see Table 3 for sample characteristics). Respondents with more than 10 years professional experience accounted for $40 \%$, which can ensure the quality of response for project planning situation. In order to assess the potential non-response bias, wave analysis was adopted [49]. Results showed that no means between the first $25 \%$ of responses and the last $25 \%$ for each of the scale were significantly different at $p=0.05$, indicating that non-response bias is not a serious issue in this study. 
Table 3. Sample characteristics.

\begin{tabular}{ccc}
\hline & & Percentage \\
\hline \multirow{2}{*}{ Gender } & Male & $86 \%$ \\
& Female & $14 \%$ \\
\hline Professional & $1-3$ & $20 \%$ \\
experience (in & $3-5$ & $16 \%$ \\
years) & $5-8$ & $15 \%$ \\
& $8-10$ & $9 \%$ \\
Number of team & $>10$ & $40 \%$ \\
members & $1-20$ & $41 \%$ \\
& $20-50$ & $27 \%$ \\
& $50-100$ & $18 \%$ \\
& $100-200$ & $5 \%$ \\
Company type & $200-500$ & $4 \%$ \\
& $>500$ & $5 \%$ \\
\hline \multirow{2}{*}{ Industry } & State-owned & $74 \%$ \\
& Private & $21 \%$ \\
& Multinational & $5 \%$ \\
\hline & Energy & $38 \%$ \\
& Civil Engineering & $25 \%$ \\
& Hydroelectric & $12 \%$ \\
& Petrochemical & $6 \%$ \\
& Transportation & $4 \%$ \\
& Others & $15 \%$ \\
\hline & &
\end{tabular}

\subsubsection{Exploratory Factor Analysis}

We conducted exploratory factor analysis (EFA) so as to identify items that share significant variance and explore the dimensions of SPP. Even through sample size is a potential issue to conduct exploratory and confirmatory factor analysis at the same time, Guadagnoli and Velicer [49] stated that there is no theoretical or empirical reasoning for a specific sample size. Therefore, we assigned all cases to an exploratory (153 cases) and a confirmatory (150 cases) data set randomly [50]. At the beginning, the corrected item-total correlations for 25 items of SPP with the exploratory data set were calculated. 11 items with an item-total correlation less than 0.5 were omitted for the low inter-correlation, leaving 14 items for the next step. Then, the bivariate correlations of all items were examined to ensure that none was more than 0.9 as suggested by Field [51].

The principal axis factor analysis with oblique rotation was adopted to test those 14 items. The Bartlett's Test of Sphericity being statistically significant $(894.93, \mathrm{df}=91, p<0.000)$, with the "meritorious" Kaiser-Meyer-Olkin index 0.851 [52]. Factors were allowed to share variance in the context of exploratory factor analysis with oblique (Promax) rotation, which is deemed suitable in this situation, as we expected the factors of the SPP scale are likely to be sub-dimensions of a common construct.

A three-factor solution explained a total of $59.80 \%$ of the variance, which reveals the consistency to theory by factor analysis. Table 4 reports the structure matrix and provides ranges, means, standard deviations, Cronbach's alphas, and factor loadings of each item. Internal consistency reliability of the three factors of SPP was sufficient by calculating the Cronbach's alpha (Factor $1=0.813$, Factor $2=0.823$, Factor $3=0.723$ ), according to the recommended reliability value of 0.70 [53]. Based on specific psychometric criteria, factor loadings of all 14 items were ranging between 0.533 and 0.835 . Thus, these 14 items was retained to serve the final stage of scale development process. 
Table 4. Scale items, descriptive statistics and factor loadings.

\begin{tabular}{|c|c|c|c|c|}
\hline Factor Item & Range & Mean & SD & Factor Loading \\
\hline \multicolumn{5}{|l|}{ Factor $1($ alpha $=0.813)$} \\
\hline $\begin{array}{l}\text { MC1 Our project plan includes managerial control } \\
\text { measures for project implementation. }\end{array}$ & $1-5$ & 3.93 & 0.87 & 0.572 \\
\hline $\begin{array}{l}\text { MC2 We implement project task in accordance with the } \\
\text { managerial control measures setting in project plan. }\end{array}$ & $1-5$ & 3.93 & 0.85 & 0.669 \\
\hline $\begin{array}{l}\text { MC3 Project planning deliverables were used by project } \\
\text { manager to control team member sustainably. }\end{array}$ & $1-5$ & 3.90 & 0.88 & 0.663 \\
\hline $\begin{array}{l}\text { MC4 Project quality management was implemented } \\
\text { sustainably based on the project plan. }\end{array}$ & $1-5$ & 3.97 & 0.93 & 0.774 \\
\hline $\begin{array}{l}\text { MC5 We track and monitor project progress effectively } \\
\text { according to project plan. }\end{array}$ & $1-5$ & 3.94 & 0.89 & 0.733 \\
\hline \multicolumn{5}{|l|}{ Factor $2($ alpha $=0.823)$} \\
\hline $\begin{array}{l}\text { RR1 Project potential risks were identified during project } \\
\text { planning process. }\end{array}$ & $1-5$ & 3.82 & 0.93 & 0.675 \\
\hline $\begin{array}{l}\text { RR2 Our project planning deliverables contain the } \\
\text { evaluation results for potential risks. }\end{array}$ & $1-5$ & 3.36 & 1.05 & 0.835 \\
\hline $\begin{array}{l}\text { RR3 Solutions for potential risks will be exported after } \\
\text { project planning process. }\end{array}$ & $1-5$ & 3.53 & 1.11 & 0.704 \\
\hline $\begin{array}{l}\text { RR4 We usually avoid the potential risk proactively } \\
\text { during project planning process. }\end{array}$ & $1-5$ & 3.45 & 0.87 & 0.671 \\
\hline $\begin{array}{l}\text { RR5 We can respond the risk emerging from project } \\
\text { implementation process effectively with project plan. }\end{array}$ & $1-5$ & 3.61 & 0.87 & 0.556 \\
\hline \multicolumn{5}{|l|}{ Factor $3($ alpha $=0.723)$} \\
\hline $\begin{array}{l}\text { WC1 Project team will jointly decompose project } \\
\text { activities during project planning process. }\end{array}$ & $1-5$ & 4.03 & 0.73 & 0.645 \\
\hline $\begin{array}{l}\text { WC2 Our project members always negotiate with the } \\
\text { conflicting issues of project plan together. }\end{array}$ & $1-5$ & 4.09 & 0.81 & 0.650 \\
\hline $\begin{array}{l}\text { WC3 Our team members acknowledge project's baseline } \\
\text { plan unanimously. }\end{array}$ & $1-5$ & 3.82 & 0.81 & 0.709 \\
\hline $\begin{array}{l}\text { WC4 We will follow the steps from predetermined } \\
\text { project plan to implement project sustainably. }\end{array}$ & $1-5$ & 3.64 & 0.86 & 0.533 \\
\hline
\end{tabular}

Extraction method: Principal axis factoring. Rotation method: Promax with Kaiser normalization.

\subsubsection{Naming the SPP Dimensions}

The exploratory factor analysis suggested that the sustainable project planning consists of three dimensions, with each measured respectively by five, five and four items. The first dimension plays a dominant role, explaining $41.40 \%$ of the total variance of SPP, while the second and third dimensions account for $10.38 \%$ and $8.02 \%$ separately. The significant correlation between three factors is shown in Table 5.

Table 5. Correlations between factor scores.

\begin{tabular}{cccc}
\hline & Factor 1 & Factor 2 & Factor 3 \\
\hline Factor 1 (Managerial Control) & 1 & $0.570^{\mathrm{a}}$ & $0.700^{\mathrm{a}}$ \\
Factor 2 (Risk Response) & $0.570^{\mathrm{a}}$ & 1 & $0.537^{\mathrm{a}}$ \\
Factor 3 (Work Consensus) & $0.700^{\mathrm{a}}$ & $0.537^{\mathrm{a}}$ & 1 \\
\hline
\end{tabular}

Factor 1-Managerial Control (MC)

The first factor was loaded by five items. The majority of items relate to the extent that a sustainable project planning process and its deliverables can guide, monitor and control project sustainably, 
which reflect on the setting managerial control measures in project planning stage and utilizing them sustainably in construct engineering project life cycle. We call this factor "Managerial Control" and discuss it in Section 4.

Factor 2-Risk Response (RR)

The second factor also correlate with five items. These items relate to identifying, analyzing, preventing, and coping potential risks raised from construction engineering projects, which indicated the sub-dimension of sustainable project planning is with respect to sustainable risk management and the proactive efforts in project planning to reduce resource waste, cost and time risk, and social conflicts. Therefore, we define this dimension as Risk Response.

Factor 3-Work Consensus (WC)

The third factor are composed of four items, which are all related to team member's sustainable perception of project planning process and outcome. Items suggests that sustainable project planning in construction engineering projects will also concern the identity situation of team member as stakeholders to project plan, which is expressed in the collaboration, communication, negotiation and recognition among project team during project life cycle.

\subsubsection{Confirmatory Factor Analysis}

For the requirements of reliability and validity of measurement scale, a confirmatory factor analysis (CFA) was performed to load all the items on their constructs respectively and to confirm the proposed structure of SPP scale with different data set from exploratory factor analysis. Following Koufteros et al.'s suggestion, the LISREL version 8.7 was used to fit a hierarchical series of confirmatory factor analysis and verify the factor structure of SPP [54]. Table 6 reports the CFA results.

Table 6. Differences in fit for alternative CFA models.

\begin{tabular}{ccccc}
\hline & $\begin{array}{c}\text { Model 1-One } \\
\text { First Order Factor }\end{array}$ & $\begin{array}{c}\text { Model 2-Three } \\
\text { First Order Factors } \\
\text { (Uncorrelated) }\end{array}$ & $\begin{array}{c}\text { Model 3-Three } \\
\text { First Order Factors } \\
\text { (Correlated) }\end{array}$ & $\begin{array}{c}\text { Model 4-Three First } \\
\text { Order and one } \\
\text { Second Order Factor }\end{array}$ \\
\hline Chi-square (df) & $359.98(75)$ & $337.22(75)$ & $188.59(72)$ & $181.89(71)$ \\
Chi-square/df & 4.79 & 4.49 & 2.62 & 2.56 \\
NFI & 0.87 & 0.86 & 0.93 & 0.93 \\
PNFI & 0.72 & 0.71 & 0.73 & 0.73 \\
CFI & 0.90 & 0.89 & 0.95 & 0.96 \\
RMSEA & 0.16 & 0.15 & 0.10 & 0.09 \\
\hline
\end{tabular}

Four Models were included in Table 5. SPP is assumed to be a single factor with 14 items in Model 1. Alternative models are contrasted by adopting a set of goodness-of-fit measures for each individual model. The fourth model appears to be the exceptional case of Model 3, with the extra restriction of structure imposed on correlations among the first-order factors. Especially for the significant difference between Model 4 and Model $1\left(\Delta \chi^{2}=178.09, \mathrm{df}=4, p<0.000\right)$, implies the discriminant validity of the factorial structure of SPP and demonstrates that Sustainable Project Planning is a single construct with second order factor [55].

Table 7 reports the standardized regression weights for each item of SPP, together with two sets of reliability measures (construct reliability (CR), and Cronbach's alpha), as well as the average variance extracted (AVE) for each individual factor. The acceptable threshold for both CR and $\alpha$ is 0.7 [56], and 0.45 for AVE [57]. The regression coefficients ought to be no less than 0.5 and statistically significant. As Table 7 shows, all indicators of each hypothesized latent construct are significantly loaded. The AVE for each individual construct was greater than the squared correlation between each sets of constructs, which providing the evidence for discriminant validity of the items [58]. 
Table 7. CFA factor analysis for sustainable project planning scale.

\begin{tabular}{cccc}
\hline & \multicolumn{1}{c}{ Standardized Regression Coefficient } & Reliability \\
\hline & MC1 & $0.68^{\mathrm{a}}$ & \\
Managerial & MC2 & $0.81^{\mathrm{a}}$ & $\mathrm{CR}=0.87 ; \mathrm{AVE}=0.57 ; \alpha=0.80$ \\
Control & $0.73^{\mathrm{a}}$ & \\
& MC4 & $0.72^{\mathrm{a}}$ & \\
& MC5 & $0.83^{\mathrm{a}}$ & \\
& RR1 & $0.62^{\mathrm{a}}$ & \\
Risk & RR2 & $0.51^{\mathrm{a}}$ & \\
Response & RR3 & $0.77^{\mathrm{a}}$ & \\
& RR4 & $0.90^{\mathrm{a}}$ & \\
& RR5 & $0.82^{\mathrm{a}}$ & \\
& WC1 & $0.57^{\mathrm{a}}$ & \\
Work & WC2 & $0.74^{\mathrm{a}}$ & \\
Consensus & WC3 & $0.65^{\mathrm{a}}$ & \\
& WC4 & $0.76^{\mathrm{a}}$ & \\
& $\mathrm{a}$ Regression coefficient is significant at the 0.01 level.
\end{tabular}

\subsubsection{Construct Validity}

The development of SPP scale ended with testing its construct validity related to project outcomes. Construct validity is confirmed by a construct's distinct antecedents and consequences, examining theoretical associations between hypothesized constructs and other constructs retrieved from the extant literature [59]. With aim of evaluating the construct validity of items of the SPP scale, structural equation modeling was adopted to investigate one consequence-Project Success which are identified from the past research [14]. Figure 1 describes the structural model for testing construct validity. The results are presented in Table 8, demonstrate a statistically significant standardized regression weight for project success and show strong predictive validity for the Sustainable Project Planning Scale at the dimension, sub-dimension, or overall level.

Table 8. Standardized regression weights for structural model.

\begin{tabular}{cc}
\hline & Project Success as Dependent \\
\hline SPP->Managerial Control standardized regression weight & 0.93 \\
SPP->Risk Response standardized regression weight & 0.77 \\
SPP->Work Consensus standardized regression weight & 0.88 \\
SPP->Project Success standardized regression weight & 0.63 \\
Chi-square (df) & $369.54(164)$ \\
Chi-square/df & 2.25 \\
NFI & 0.95 \\
PNFI & 0.82 \\
CFI & 0.97 \\
GFI & 0.89 \\
\hline
\end{tabular}

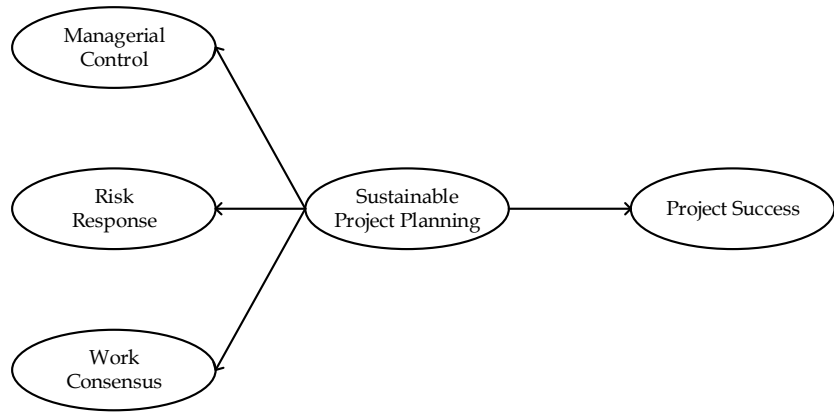

Figure 1. Structural Model. 


\section{Discussion}

While Project Planning is a well-known theoretical concept in the literature on project management, we know little about what extent of efforts should be invested in the project planning stage for sustainable project management, and how to evaluate the sustainable project planning of construction engineering projects appropriately. This paper supported this argument, and provided a definition of a new construct, sustainable project planning. It also developed a scale (SPP) that evaluates the level of project planning on considering of sustainability successfully and predicted project success of construction engineering projects in a project life cycle.

Interviews and a survey were conducted to collect data for scale development of sustainable project planning. The results showed that construction engineering projects with sustainable project planning are distinguished from those that are less so by the extent of managerial control, risk response, and work consensus that their sustainable project planning triggers in a project life cycle. From the core needs of sustainable project organizations, sustainable project planning in construction engineering projects need to guarantee sustainable project management in a project life cycle. Thus, from the internal perspective of sustainability in project management, sustainable project planning reflects the efforts of project planning practices for economic, social, environmental sustainability. Three dimensions of SPP are almost consistent with Silvius and Schipper's [12] statement about competence gap of project managers concerning sustainability, particularly in systems thinking competencies, anticipatory competencies, and interpersonal competencies. Thus, in line with current researchers, the sustainability in construction engineering projects requires sustainable project planning to achieve self-sustaining and self-remaining in project life cycle [60].

We chose to call the first dimension "Managerial Control". Managerial control fits within the broader concept of "control", which refers to any attempt for motivating others to follow instructions consistent with organizational objectives [61]. Sustainable project planning as a process to setting up a project control system involves specific rules, procedures and policies, can regulate the use of resources, procedures, or outcomes of projects sustainably [18,62]. Therefore, the central representation of sustainable project planning provides a structure and yardstick for monitoring, reviewing and controlling project execution in the whole project delivery process [5,63]. Five items are all related to setting and playing the directing, monitoring and controlling role of sustainable project planning in project life cycle, which reflects the extent to which project planning can guarantee cost of producing, waste reduction, democratic processes and responsible governance structures sustainably in construction engineering projects.

Risk Response, the second dimension, refers to sustainable project planning deal with risks comes out of whole construction engineering project life cycle. Stemming from the needs of sustainability and following the life cycle management method, project risks need to be identified and taken with a precautionary approach [64]. Thus, planning is a critical stage of project risk management and sustainable project planning effort is viewed as a critical risk management tool to reduce uncertainty for high risk projects like construction engineering projects [26]. As Nidumolu [65] mentioned, sustainable project planning can help manage uncertainties by way of effective and sustainable planning, estimation, and prioritization of project activities, and the pre-management of underlying problems within the project context. Five items refer to the extent that project identifying, evaluating, preventing and responding risks based on sustainable project planning effort, which fits the requirement of economic, environmental, and social sustainability forcefully.

The third dimension, which we call "Work Consensus", focuses on the social and soft role of sustainable project planning in maintaining the sustainability of construction engineering projects. Project planning is not only reflecting the "technical" aspect of the project, but still can develop "soft" environment for project team [66]. Especially for sustainable project planning, the social sustainability need more support from the commitment of project team in the project life cycle. For construction engineering projects with complex stakeholders, sustainable project planning increases the opportunity for communication and likelihood that each team member understands what other 
member are proposing to do [67], and then facilitates common understanding and knowledge sharing at project team level [68]. Thus, sustainable project planning also manifests as the efforts made on realizing common commitment and democracy to the goals, values, and behavioral expectations of construction engineering project team. Four items focus on the function of sustainable project planning on driving consentaneous work identity and commitment in construction engineering project life cycle, which guarantee sustainable project management intrinsically.

SPP successfully predicted project success of construction engineering projects, indicated that sustainable project planning is a critical factor to affect the success of construction engineering projects, which is in accordance with results of previous empirical researches [24].

\section{Conclusions and Implications}

Sustainable construction engineering emphasizes the significance of integrating sustainability into project planning, monitoring, evaluation and decision making to enhance project quality [69]. As a bridge to link planning phase and execution phase, project planning can affect sustainability-related objectives of construction engineering directly. Thus, what kind of effort should be made in sustainable project planning activities and what is the core role of sustainable project planning are the core questions to be answered. Although there is an increasing amount of literature about the evaluation of project planning in project management field, few studies focused on the sustainable project planning in a project life cycle, or emphasis sustainable function-based evaluation. As the current focus of sustainability is integrated in construction engineering projects, it is necessary to explore the concept of sustainable project planning in this context. Our research provided a definition of sustainable project planning in the contextual setting of construction engineering projects, and developed a new scale to evaluate it. Results show that sustainable project planning is an instrument of life cycle management, and also indicate that the sustainable project planning manifested three dimensions: managerial control, risk response and work consensus. At the same time, sustainable project planning predicts project success of construction engineering projects successfully, indicates that sustainable project planning is an important tool to maintain sustainability for construction engineering projects.

The theoretical implication of the present study is twofold. First, we demonstrated the concept of sustainable project planning and developed a measurement scale in construction engineering projects for sustainable project management. The SPP scale may measure sustainable project planning from a sustainable project management perspective and stimulate more empirical researches on the critical role of sustainable project planning in realizing sustainability. This SPP scale could also be regarded as a new point for studying project planning in construction engineering projects, which may provide basis for the sustainable planning and control study in construction engineering project context.

SPP can be adopted together with measures of project success to evaluate the extent of efforts on sustainable project planning. The acknowledgement of SPP as a construct with three inter-related sub-dimensions provides implications for sustainable project management. Managers of construction engineering projects can evaluate and improve the extent of sustainable project planning of their projects by using the scale of SPP, and need to pay more attention to the role of their project planning on directing and controlling project, reducing project risks and forming common understanding and commitment to projects for project sustainability. These separated but inter-related dimensions imply that the PMO and project managers ought to pay attention to them individually and foster their development in management practice. Sustainable project management needs efforts on three functions simultaneously during project planning to ensure sustainability in a project life cycle.

We showed that SPP successfully predicts project success from construction engineering projects in China, which implies limitation of samples and conclusion generalization. However, even though this scale stemmed from the construction engineering industry, the scale items are not only exclusive to this industry, and future research can focus on the sustainable project planning and its impact on project outcome in another project context. Similar research can be conducted worldwide to compare 
the differences between projects with different culture and enhance generalization of SPP scale, and to deepen the concept of sustainable project planning.

In conclusion, this study explored the concept of sustainable project planning and provided an instrument with high validity and reliability for assessing it in construction engineering projects. The measurability of the sustainable project planning from a sustainable management perspective enables us to understand project planning and sustainability better. By understanding the core role of sustainable project planning and the efforts should be invested in sustainable project planning activities, managers will be able to better organize and manage construction engineering projects in a more sustainable way.

Acknowledgments: This publication has been developed and reproduced with grants from the National Natural Science Foundation of China (71702022, 71772024, 71702023), China Postdoctoral Science Foundation (2017M621142). Unauthorized reproduction of this material is strictly prohibited.

Author Contributions: Miao Yu, Fangwei Zhu and Xiaotian Yang together designed this study and completed the paper in English, Linzhuo Wang participated in drafting the paper and critically revised it for important intellectual content, Xiuxia Sun provided many good research advices and revised the manuscript.

Conflicts of Interest: The authors declare no conflict of interest.

\section{Appendix A}

Table A1. Original Scale Items.

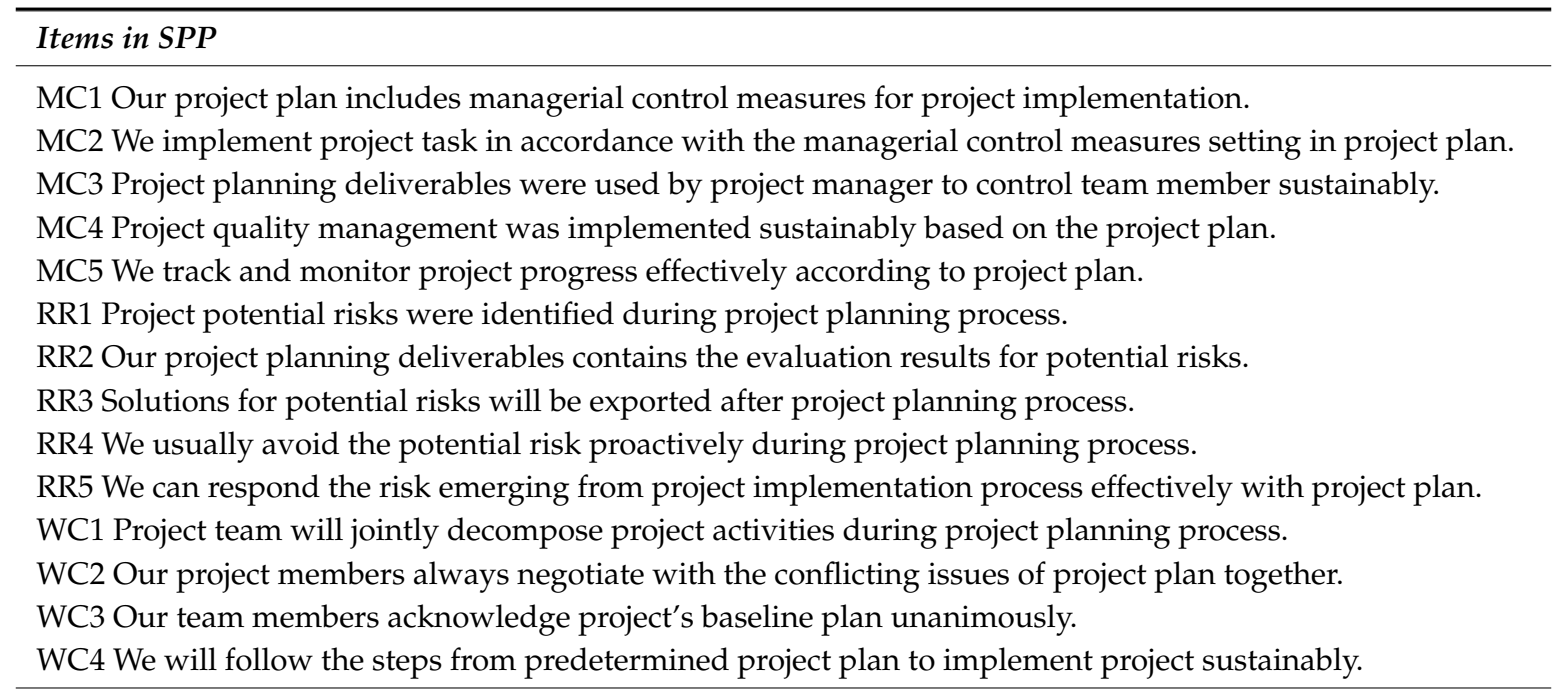

\section{Omitted Items}

Our project plan reflect project objectives well.

Our project plan contains appraisal target for each person in charge.

Our project plan will cover all of project activities.

Project planning in our projects is a process of balancing multiple objectives.

Our final project plan usually with clear assumption files.

Methods for coordinating cross-functional activities were included in project plan.

Milestone plan for phase control were included in our project plan.

The existing resource situation were manifested in our project plan.

We usually conduct analysis of the needs of users in project planning phase.

Previous project planning template will used in project planning process.

Project planning software will be used in project planning process. 


\section{References}

1. Martens, M.L.; Carvalho, M.M. Key factors of sustainability in project management context: A survey exploring the project managers' perspective. Int. J. Proj. Manag. 2017, 35, 1084-1102. [CrossRef]

2. Schröpfer, V.L.M.; Tah, J.; Kurul, E. Mapping the knowledge flow in sustainable construction project teams using social network analysis. Eng. Constr. Archit. Manag. 2017, 24, 229-259. [CrossRef]

3. Banihashemi, S.; Hosseini, M.R.; Golizadeh, H.; Sankaran, S. Critical success factors (CSFs) for integration of sustainability into construction project management practices in developing countries. Int. J. Proj. Manag. 2017, 35, 1103-1119. [CrossRef]

4. Gareis, R.; Huemann, M.; Martinuzzi, A. Project Management and Sustainable Development Principles; Project Management Institute: Philadelphia, PA, USA, 2013.

5. Marcelino-Sádaba, S.; González-Jaen, L.F.; Pérez-Ezcurdia, A. Using project management as a way to sustainability from a comprehensive review to a framework definition. J. Clean. Prod. 2015, 99, 1-16. [CrossRef]

6. Sfakianaki, E. Resource-efficient construction: Rethinking construction towards sustainability. World J. Sci. Technol. Sustain. Dev. 2015, 12, 233-242. [CrossRef]

7. Chakraborty, S.; Jo, B.W.; Jo, J.H.; Baloch, Z. Effectiveness of sewage sludge ash combined with waste pozzolanic minerals in developing sustainable construction material: An alternative approach for waste management. J. Clean. Prod. 2017, 153, 253-263. [CrossRef]

8. Wu, G. A multi-objective trade-off model in sustainable sonstruction projects. Sustainability 2017, 9, 1929. [CrossRef]

9. Van Marrewijk, A.; Clegg, S.R.; Pitsis, T.S.; Veenswijk, M. Managing public-private megaprojects: Paradoxes, complexity, and project design. Int. J. Proj. Manag. 2008, 26, 591-600. [CrossRef]

10. Chang, R.D.; Soebarto, V.; Zhao, Z.Y.; Zillante, G. Facilitating the transition to sustainable construction: China's policies. J. Clean. Prod. 2016, 131, 534-544. [CrossRef]

11. Kivilä, J.; Martinsuo, M.; Vuorinen, L. Sustainable project management through project control in infrastructure projects. Int. J. Proj. Manag. 2017, 35, 1167-1183. [CrossRef]

12. Silvius, A.J.G.; Schipper, R.; Planko, J.; van den Brink, J.; Köhler, A. Sustainability in Project Management; Gower Publishing: Farnham, UK, 2012.

13. Silvius, G.; Schipper, R.P.J. Sustainability in project management: A literature review and impact analysis. Soc. Bus. 2014, 4, 63-96. [CrossRef]

14. Carvalho, M.M.; Rabechini, R. Can project sustainability management impact project success? An empirical study applying a contingent approach. Int. J. Proj. Manag. 2017, 35, 1120-1132. [CrossRef]

15. Siew, R.Y.J. Integrating sustainability into construction project portfolio management. KSCE J. Civ. Eng. 2016, 20, 101-108. [CrossRef]

16. PMI. A Guide to the Project Management Body of Knowledge (PMBOK Guide), 5th ed.; Project Management Institute: Newtown Square, PA, USA, 2013.

17. Hamilton, M.R.; Gibson, G.E., Jr. Benchmarking preproject planning effort. J. Manag. Eng. 1996, 12, $25-33$. [CrossRef]

18. Aarseth, W.; Ahola, T.; Aaltonen, K.; Økland, A.; Andersen, B. Project sustainability strategies: A systematic literature review. Int. J. Proj. Manag. 2017, 35, 1071-1083. [CrossRef]

19. Dvir, D.; Lechler, T. Plans are nothing, changing plans is everything: The impact of changes on project success. Res. Policy 2004, 33, 1-15. [CrossRef]

20. Little, B. The principles of successful project management. Hum. Resour. Manag. Int. Dig. 2011, 19, 36-39. [CrossRef]

21. Boz, M.A.; El-adaway, I.H. Modification of advanced programmatic risk analysis and management model for the whole project life cycle's risks. J. Constr. Eng. Manag. 2013, 138, 51-60. [CrossRef]

22. Crosby, P.B. Quality Is Free; McGraw-Hill: New York, NY, USA, 1979.

23. Ibbs, C.W.; Kwak, Y.-H. Assessing project management maturity. Proj. Manag. J. 2000, 31, 32-43.

24. Zwikael, O.; Pathak, R.D.; Singh, G.; Ahmed, S. The moderating effect of risk on the relationship between planning and success. Int. J. Proj. Manag. 2014, 32, 435-441. [CrossRef]

25. Meredith, J.R.; Mantel, S.J., Jr. Project Management-A Managerial Approach, 6th ed.; John Wiley and Sons: Hoboken, NJ, USA, 2006. 
26. Zwikael, O.; Sadeh, A. Planning effort as an effective risk management tool. J. Oper. Manag. 2007, $25,755-767$. [CrossRef]

27. Laufer, A.; Kusek, J.; Cohenca-Zall, D. Taking the sting out of project surprises. Optimum 1997, $27,1-7$.

28. Pich, M.T.; Loch, C.H.; Meyer, A. De On Uncertainty, ambiguity, and complexity in project management. Manag. Sci. 2002, 48, 1008-1023. [CrossRef]

29. Bachy, G.; Hameri, A.-P. What to be implemented at the early stage of a large-scale project. Int. J. Proj. Manag. 1997, 15, 211-218. [CrossRef]

30. Stockstrom, C.; Herstatt, C. Planning and uncertainty in new product development. RED Manag. 2008, 38, 480-490. [CrossRef]

31. Kerzner, H. Project Management: A Systems Approach to Planning, Scheduling and Controlling, 9th ed.; John Wiley and Sons: Hoboken, NJ, USA, 2006.

32. Laufer, A.; Tucker, R.L. Is construction project planning really doing its job? A critical examination of focus, role and process. Constr. Manag. Econ. 1987, 5, 243-266. [CrossRef]

33. De Carvalho, M.M.; Rabechini Junior, R. Impact of risk management on project performance: The importance of soft skills. Int. J. Prod. Res. 2015, 53, 321-340. [CrossRef]

34. Faniran, O.O.; Oluwoye, J.O.; Lenard, D.J. Interactions between construction planning and influence factors. J. Constr. Eng. Manag. 1998, 124, 245-256. [CrossRef]

35. Tasevska, F.; Damij, T.; Damij, N. Project planning practices based on enterprise resource planning systems in small and medium enterprises-A case study from the Republic of Macedonia. Int. J. Proj. Manag. 2014, 32, 529-539. [CrossRef]

36. Salomo, S.; Weise, J.; Gemünden, H.G. NPD Planning activities and innovation performance: The mediating role of process management and the moderating effect of product innovativeness. J. Prod. Innov. Manag. 2007, 24, 285-302. [CrossRef]

37. Cho, C.-S.; Gibson, G.E., Jr. Building project scope definition using project definition rating index. J. Archit. Eng. 2001, 7, 115-125. [CrossRef]

38. Zwikael, O.; Globerson, S. Evaluating the quality of project planning: A model and field results. Int. J. Prod. Res. 2004, 42, 1545-1556. [CrossRef]

39. Grover, V.; Goslar, M.D. The initiation, adoption, and implementation of telecommunications technologies in US organizations. J. Manag. Inf. Syst. 1993, 10, 141-164. [CrossRef]

40. Puddicombe, M.S. The limitations of planning: The importance of learning. J. Constr. Eng. Manag. 2006, 132, 949-955. [CrossRef]

41. Papke-shields, K.E.; Boyer-wright, K.M. ScienceDirect Strategic planning characteristics applied to project management. Int. J. Proj. Manag. 2017, 35, 169-179. [CrossRef]

42. Churchill, G.A. A Paradigm for developing better measures of marketing constructs. J. Mark. Res. 1979, $16,64$. [CrossRef]

43. Flynn, L.R.; Pearcy, D. Four subtle sins in scale development: Some suggestions for strengthening the current paradigm. Mark. Res. Soc. 2001, 43, 409-423. [CrossRef]

44. Stratman, J.K.; Roth, A.V. Enterprise resource planning (ERP) competence constructs: Two-stage multi-item scale development and validation. Decis. Sci. 2002, 33, 601-628. [CrossRef]

45. Creswell, J. Research Design, Qualitative and Quantitative Approaches; SAGE Publications: London, UK, 1994.

46. Hambrick, D.C. Strategic awareness within top management teams. Strateg. Manag. J. 1981, 2, $263-279$. [CrossRef]

47. Papke-Shields, K.E.; Beise, C.; Quan, J. Do project managers practice what they preach, and does it matter to project success? Int. J. Proj. Manag. 2010, 28, 650-662. [CrossRef]

48. Ilieva, J.; Baron, S.; Healey, N.M. Online surveys in marketing research: Pros and cons. Int. J. Mark. Res. 2002, 44, 361-376. [CrossRef]

49. Guadagnoli, E.; Velicer, W.F. Relation to sample size to the stability of component patterns. Psychol. Bull. 1988, 103, 265-275. [CrossRef] [PubMed]

50. Todorovic, Z.W.; McNaughton, R.B.; Guild, P. ENTRE-U: An entrepreneurial orientation scale for universities. Technovation 2011, 31, 128-137. [CrossRef]

51. Field, A. Discovering Statistics Using SPSS, 2nd ed.; Sage Publications: Thousand Oaks, CA, USA, 2005.

52. Kaiser, H.F. An index of factorial simplicity. Psychometrika 1974, 39, 31-36. [CrossRef]

53. Nunnally, J.C.; Bernstein, I.H. Psychometric Theory, 3rd ed.; McGraw-Hill: New York, NY, USA, 1994. 
54. Koufteros, X.; Babbar, S.; Kaighobadi, M. A paradigm for examining second-order factor models employing structural equation modeling. Int. J. Prod. Econ. 2009, 120, 633-652. [CrossRef]

55. Widaman, K.F. Hierarchically nested covariance structure models for multitrait-multimethod data. Appl. Psychol. Meas. 1985, 9, 1-26. [CrossRef]

56. Hair, J.F.; Black, W.C.; Babin, B.J.; Anderson, R.E.; Tatham, R.L. Multivariate Data Analysis, 6th ed.; Pearson-Prentice Hall: Englewood Cliffs, NJ, USA, 2006.

57. Netemeyer, R.G.; Bearden, W.O.; Sharma, S. Scaling Procedures: Issues and Applications; Sage Publications: Thousands Oak, CA, USA, 2003.

58. Fornell, C.; Larcker, D.F. Evaluating structural equation models with unobservable variables and measurement error. J. Mark. Res. 1981, 18, 39. [CrossRef]

59. Iacobucci, D.; Ostrom, A.; Grayson, K. Distinguishing service quality and customer satisfaction: The voice of the consumer. J. Consum. Psychol. 1995, 4, 277-303. [CrossRef]

60. De Araújo, G.C.; Mendonça, P.S.M. Analysis of implantation process of enterprise sustainability rules: Study of case in the beef agro industry. RAM. Rev. Adm. Mackenzie 2009, 10, 31-56. [CrossRef]

61. Kirsch, L.J. Deploying common systems globally: The dynamics of control. Inf. Syst. Res. 2004, 15, $374-395$. [CrossRef]

62. Eisenhardt, K.M. Control: Organizational and economic approaches. Manage. Sci. 1985, 31, 134-149. [CrossRef]

63. Laufer, A.; Tucker, R.L.; Shapira, A.; Shenhar, A.J. The multiplicity concept in construction project planning. Constr. Manag. Econ. 1994, 12, 53-65. [CrossRef]

64. Silvius, G. Sustainability as a competence of Project Managers. PM World J. 2016, 9, 1-13.

65. Nidumolu, S. The effect of coordination and uncertainty on software project performance: Residual risk as an international variable. Inf. Syst. Res. 1995, 6, 191-219. [CrossRef]

66. Thomas, M.; Jacques, P.H.; Adams, J.R.; Kihneman-Wooten, J. Developing an effective project: Planning and team building combined. Proj. Manag. J. 2008, 39, 105-113. [CrossRef]

67. Reich, B.H.; Gemino, A.; Sauer, C. How knowledge management impacts performance in projects: An empirical study. Int. J. Proj. Manag. 2014, 32, 590-602. [CrossRef]

68. Lederer, A.L.; Mendelow, A.L. Convincing top management of the strategic potential of information systems. MIS Q. 1988, 12, 525. [CrossRef]

69. Bebbington, J.; Brown, J.; Frame, B. Accounting technologies and sustainability assessment models. Ecol. Econ. 2007, 61, 224-236. [CrossRef] 